
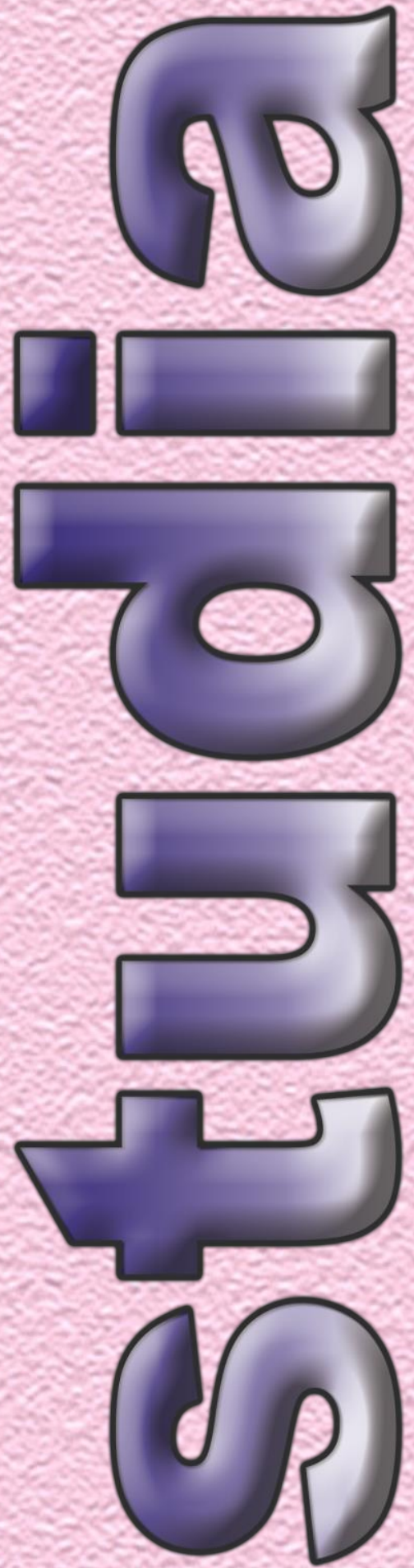

e-ISSN 2550-0589 p-ISSN 1412-0674

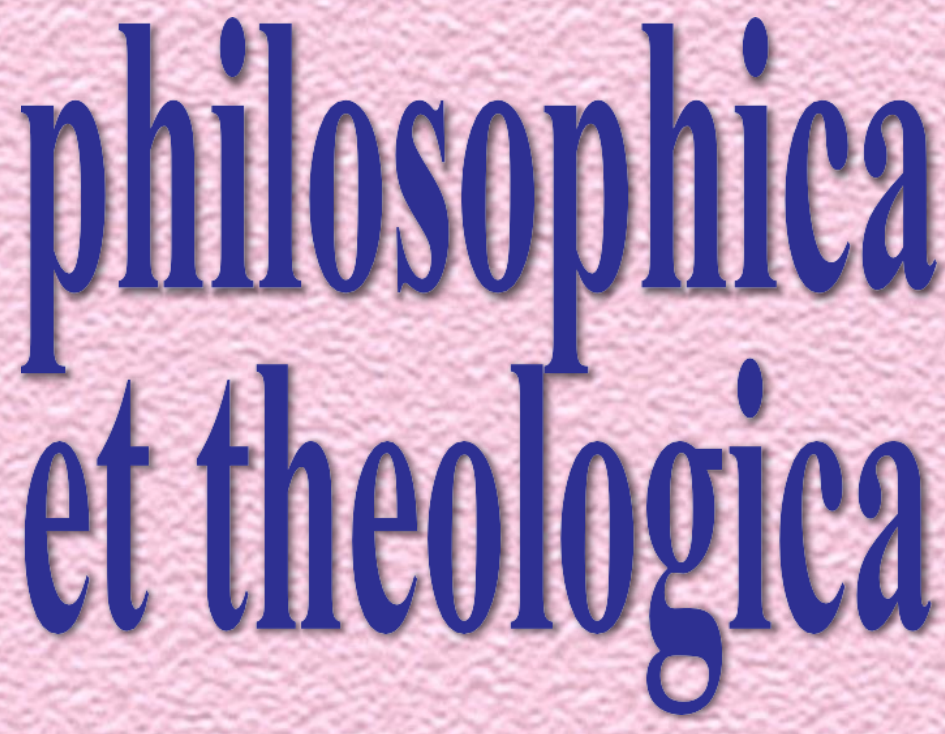

Neo-Kantianisme dan Implikasinya untuk Penelitian Terhadap Agama Donatus Sermada Kelen

Posisi Perempuan dalam Lingkaran Pengetahuan Cicilia Damayanti

Tugas Suci Umat Katolik dalam Dialog dengan Agama-agama Lain Di Indonesia

Ditinjau dari Dokumen Abu Dhabi Artikel 23-24

Agustinus Mujianto, Adry Yanto Saputro

Hati Nurani: Kesatuan Harmonis Antara Synderesis, Conscientia dan Keutamaan Kebijaksanaan Benny Phang Khong Wing

Acara Makan dalam Kultur Masa Kini dan Ekaristi

Fandi Gilar Saputro

Michael Foucault dan Feminisme Konrad Kebung

$* * * * *$

TELAAH BUKU 


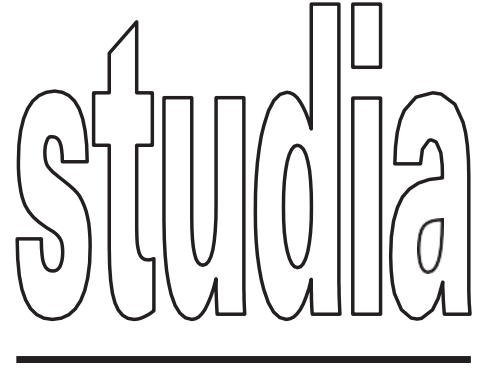

STUDIA PHILOSOPHICA ET THEOLOGICA (ISSN Print 1412-0674 and ISSN Online 2550-0589) is a bilingual (Indonesian and English language) and peer reviewed journal published by Center of Research of Widya Sasana School of Philosophy Theology, Malang. STUDIA specializes in researched papers related to contextualization and inculturation of theology and philosophy from inter-disciplinary-methodological point of view. Journal has 2 issues per year (April and October).

STUDIA welcomes philosophical and theological contributions from scholars with various background of disciplines. This journal uses English and Indonesian Language. STUDIA is an open access journal whose papers published is freely downloaded.

\section{FOCUS AND SCOPE:}

STUDIA focuses on philosophical and theological studies based on both literary and field researches. The emphasis of study is on systematic attempt of exploring seeds of Indonesian philosophy as well as contextualization and inculturation of theology in socio-political-historical atmosphere of Indonesia.

Scope of STUDIA covers various perspectives of philosophical and theological studies from interdisciplinary methodology and cultural-religious point of view of traditions.

\section{PUBLISHER :}

P3M Sekolah Tinggi Filsafat Teologi

Widya Sasana Malang

Jl. Terusan Rajabasa 2,

Malang 65146 Indonesia

Telp. $0341-552120$

Fax. 0341 - 566676

Email :stftws@gmail.com

Website : ejournal.stftws.ac.id
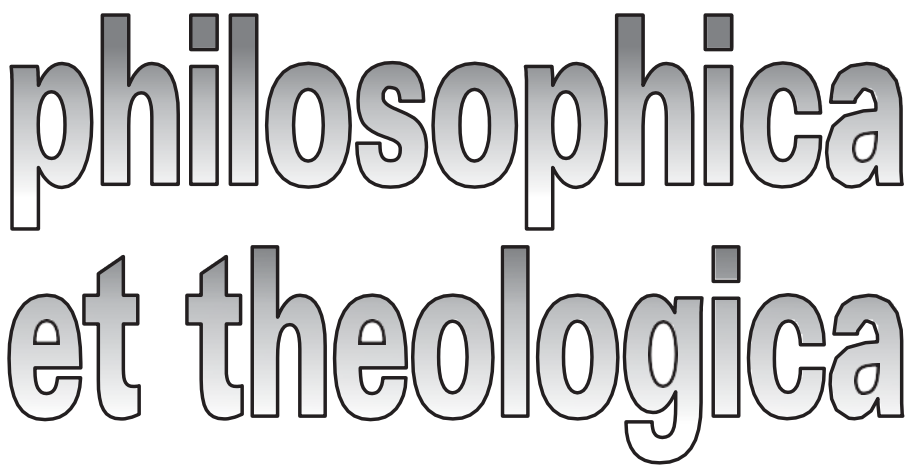

e-ISSN 2550-0589

p-ISSN 1412-0674

Editor in Chief

FX. Eko Armada Riyanto (Google Scholar; h-index: 5); Widya Sasana College of Philosophy Theology, Malang.

Managing Editors

Edison RL. Tinambunan (Google Scholar; h-index: 1): Widva Sasana College of Philosophy Theology, Malang.

Kurniawan Dwi Madyo Utomo (Google Scholar); Widya Sasana College of Philosophy Theology, Malang.

\section{Editorial Board}

Pius Pandor (Google Scholar; h-index: 2); Widya Sasana College of Philosophy Theology, Malang.

Valentinus Saeng (Google Scholar; h-index: 2); Widya Sasana College of Philosophy Theology, Malang.

Yohanes I Wayan Marianta (Google Scholar); Widya Sasana College of Philosophy Theology, Malang.

Raymundus Made Sudhiarsa (Google Scholar; h-index: 2); Widya Sasana College of Philosophy Theology, Malang.

Alphonsus Catur Raharso (Google Scholar; h-index: 2); Widya Sasana College of Philosophy Theology, Malang.

Petrus Maria Handoko (Google Scholar; h-index: 2); Widya Sasana College of Philosophy Theology, Malang.

Antonius Denny Firmanto (Google Scholar; h-index: 2); Widya Sasana College of Philosophy Theologv, Malang.

Carl Sterkens (Scopus ID: ... ; Google Scholar; $h$-index: 7); Katholic Radboud University, Nijmegen, Niederlands.

Daniel Franklin Pilario(Google Scholar; h-index: 4); Adamson University, Manila, Philippines.

Roland Tuazon (Google Scholar; h-index: 2); Adamson University, Manila, Philippines.

Emanuel P.D. Martasudjita (Scopus ID: 6026801; Google Scholar; h-index: 4); Sanata Dharma University, Yogyakarta.

Johanis Ohoitimur (Google Scholar; h-index: 3); Pineleng College, Manado.

Antonius Eddy Kristiyanto (Google Scholar; h-index: 5); Driyarkara College, Jakarta.

Mudjia Rahardja (Scopus ID: ... Google Scholar; h-index: 10); Maulana Malik Ibrahim Islamic State University, Malang.

Justinus Sudarminta (Google Scholar; h-index: 7); Driyarkara College, Jakarta.

English Language Advisor

Maria Lichmann (North Carolina)

Odilia Rahayu Widji Astuti

Indonesian Language Advisor

Didik Bagiyowinadi

Information and Technology

Imilda Retno Arum Sari

Publication Frequency

Studia Philosophicaet Theologica is published two times a year (April and October) 


\section{Author Guidelines}

1. Article must have150-word abstract in both English and Indonesian language and four or five keywords.

2. Article should be between 5000 and 8000 words, inclusive of references and footnotes.

3. Article must be a study based on either literary (text) or field research.

4. Article will be submitted in Word (single-spaced and 12-point font) for consideration by email attachment, beside online submission as required. Authors must $\log$ in before submit their article.

5. Headings:

- First-level headings (e.g. Introduction, Conclusion) should be in bold, with an initial capital letter for any proper nouns.

- Second-level headings should be in bold italics, with an initial capital letter for any proper nouns.

- Third-level headings should be in italics, with an initial capital letter for any proper nouns.

6. Notes and Bibliographies please click https:/www.dropbox.com $/ \mathrm{s} / \mathrm{y} 2 \mathrm{nb} 913 \mathrm{cvb} 9$ fg47/Notes\%20and\%20Bibliography\%20Turabian\%20Style.pdf? $d l=0$.

7. Article submitted will be peer-reviewed by qualified academics; this process may take weeks or months. All submitted papers are subject to review of the editors, editorial board, and reviewers.

8. Author should be willing to respond to questions from readers of their articles; and in case there is correction, author must refine the article as soon as possible.

\section{Guidelines for Book Reviews}

1. Please include, at the beginning: Author, Title, Place, Publisher, Date, number of pages, ISBN of the book reviewed.

E.g., Taylor, Charles. A Secular Age. Cambridge: The Belknap Press of Harvard University Press, 2007. 874+x pp. ISBN-13:978-0-674-02676-6.

2. The review begin with abstract, three or four keywords and continue with a brief overall description of the book.

3. The review may include:

- The content and its complexity of the book.

- Comments on the author's style and contribution of the book.

- Philosophical or theological methodology of presentation.

- Position of the philosophical or theological arguments in its field.

4. The preferred format for submissions is MS-Word.

5. Review should be about 1500 words long. The name, affiliation and email address of the reviewer should appear at the end of the review. 


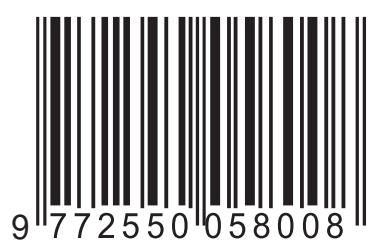




\section{Studia Philosophica et Theologica \\ E-ISSN 2550 - 0589 \\ ISSN 1412-0674}

Vol. 21 No. 2 Oktober 2021

Hal. 133 - 253

\section{DAFTAR ISI}

ART IKEL

Neo-Kantianisme dan Implikasinya

untuk Penelitian Terhadap Agama

Donatus Sermada Kelen $133-154$

Posisi Perempuan dalam Lingkaran Pengetahuan

Cicilia Damayanti $155-173$

Tugas Suci Umat Katolik

dalam Dialog dengan Agama-agama Lain Di Indonesia

Ditinjau dari Dokumen Abu Dhabi Artikel 23-24

Agustinus Mujianto, Ardy Yanto Saputro $174-194$

Hati Nurani: Kesatuan Harmonis Antara Synderesis, Conscientia dan Keutamaan Kebijaksanaan

Benny Phang Khong Wing $195-217$

Acara Makan dalam Kultur Masa Kini dan Ekaristi

Fandi Gilar Saputro $218-237$

Michael Foucault dan Feminisme

Konrad Kebung $238-247$

\section{TELAAH BUKU}

Marilogiasociale. Il significatodella Vergine per lasocietà

Gregorius Pasi $248-251$

Index $252-253$ 


\title{
TUGAS SUCI UMAT KATOLIK \\ DALAM DIALOG DENGAN \\ AGAMA-AGAMA LAIN DI INDONESIA \\ DITINJAU DARI DOKUMEN ABU DHABI ARTIKEL 23-24
}

\author{
Agustinus Mujianto, Adry Yanto Saputra \\ Prodi Magister Filsafat Teologi STFT Widya Sasana Malang \\ Email: mujiagustinus17@gmail.com, adryyantonaruto@yahoo.com
}

\begin{abstract}
The focus of the discussion of this study is on interreligious dialogue. Catholics in Indonesia have a sacred duty to dialogue with other religions. This sacred task is part of the mission given by Jesus Christ Himself to spread love in the midst of the world, which today has been hit by a humanitarian crisis where religion is used to incite people to war, hatred, violence and bloodshed. The methodology used in this study is the deductive method with analogical approach. The deductive method is a method that bases its reasoning on a certain perspective, while the analogical approach is an approach that sees the parallels of ideas between certain perspective and other perspectives. This study sees that there are parallels of ideas between the Abu Dhabi documents articles 23-24 with Raymundus Sudhiarsa's Theology of Margin and Fratelli Tutti's documents. This study found that there are five themes that can be explored in interreligious dialogue, namely the theme of religious goals, the noble values of life, peace, correct interpretation of teachings, and brotherhood.
\end{abstract}

Keywords: Dialogue, Sacred Duty, Religion, Catholics

\section{Abstrak}

Fokus pembahasan dari studi ini adalah tentang dialog antaragama. Umat Katolik di Indonesia memiliki tugas suci untuk berdialog dengan agama-agama lain. Tugas suci ini merupakan bagian dari perutusan yang diberikan oleh Yesus Kristus sendiri untuk mewartakan kasih di tengah-tengah dunia, yang sekarang ini telah dilanda oleh krisis kemanusiaan di mana agama digunakan untuk menghasut orang kepada perang, kebencian, kekerasan, dan pertumpahan darah. Metodologi yang digunakan di dalam studi ini adalah metode deduktif dengan pendekatan analogis. Metode deduktif adalah metode yang mendasarkan penalarannya pada perspektif tertentu, sedangkan pendekatan analogis adalah pendekatan yang melihat adanya kesejajaran 
gagasan antara perspektif tertentu dengan perspektif lain. Studi ini melihat ada kesejajaran gagasan antara dokumen Abu Dhabi artikel 23-24 denganTheology of Margin Raymundus Sudhiarsa dan dokumen Fratelli Tutti. Studi ini menemukan bahwa ada lima tema yang dapat digumuli di dalam dialog antaragama, yaitu tema tentang tujuan agama, nilai luhur kehidupan, perdamaian, interpretasi ajaran yang benar, dan persaudaraan

Kata Kunci: Dialog, Tugas Suci, Agama, Umat Katolik

\section{Pendahuluan}

Hidup di Indonesia berarti harus siap dan mampu untuk menjaga harmoni dengan keanekaragaman di dalamnya. Salah satu keragaman yang dimiliki oleh Indonesia adalah dalam hal agama. Indonesia bukanlah negara yang menganut sistem satu agama untuk semua, melainkan Indonesia adalah negara yang menjamin kebebasan warga negaranya untuk beribadah menurutagama dan kepercayaan masing-masing. Meskipun harus diakui bahwa In- donesia adalah negara yang mayoritas beragama Islam, tetapi negara Indo- nesia tidak serta-merta lalu mengayomi pemeluk agama Islam saja dan menganaktirikan agama lain; tidak demikian. Negara Indonesia justrumengayomi seluruh warga negaranya yang memeluk agama yang berbeda- beda tersebut.

Menyadari posisinya di Indonesia, umat Katolik ditantang untuk keluar dari dirinya sendiri. Umat Katolik tidak boleh menjadi umat yang pasif dan eksklusif. Umat Katolik harus keluar untuk berdiskusi dalam dialog dengan agama-agama lain. Berdiskusi bukan untuk pamer doktrin mana yang benar, melainkan berdiskusi dalam kerangka untuk mengusahakan kebaikankebaikan, keharmonisan, dan kedamaian di dalam tata hidup bersama. Selama umat Katolik tidak berani keluar dari dirinya sendiri, umat Katolik hanya akan menciptakan prasangka-prasangka yang semakin hari akan menumbuhkan fanatisme sempit dan kebencian. Tinggal menunggu waktu saja pada akhirnya fanatisme sempit dan kebencian ini akan pecah menjadi konflik antaragama.

Paus Fransiskus menyoroti tentang dialog dengan agama-agama lain secara serius di dalam dokumen Abu Dhabi. Nampak dalam dokumen itu pula, kemauan yang tulus dari Paus Fransiskus untuk menjalin persaudaraan dengan agama-agama lain. Dokumen Abu Dhabi ini digunakan untuk memperdalam tema yang diangkat di dalam penelitian ini. Dokumen Abu Dhabi yang digunakan difokuskan pada artikel 23-24. Berangkat dari fokus tersebut, ada tiga rumusan masalah yang hendak dijawab di dalam penelitian ini. Pertama, apa yang dikatakan oleh dokumen Abu Dhabi artikel 23-24 tentang dialog dengan agama-agama lain? Mengapa dialog dengan agama- agama lain ini penting menurut dokumen Abu Dhabi Artikel 23-24? 
Bagaimana dialog dengan agama-agama lain dikerjakan?

Penilitian tentang dokumen Abu Dhabi pernah dilakukan oleh beberapa peneliti. Siti Marfuatun pernah meneliti dokumen Abu Dhabi dengan judul penelitan "Pandangan Paus Fransiskus Tentang Perdamaian Dunia dalam Dokumen Konferensi Global di Abu Dhabi", dari penelitian tersebut dia menemukan faktorfaktor penyebab konflik dan solusi untuk perdamaian menurut dokumen tersebut, tetapi pembahasannya masih dalam bentuk pembahasan secara umum. Konstantinus Frederikus Jawa pernah meneliti dokumen Abu Dhabi dengan judul penelitian "Pendidikan Demokrasi, Persaudaraan, dan Persatuan Indonesia dalam Terang Dokumen Persaudaraan Manusia," ${ }^{2}$ dari penelitian tersebut dia menemukan bahwa membangun persaudaraan manusia dalam pendidikan meminta siswa untuk dibina melakukan dialog kehidupan dan diberi kesempatanuntuk bertemu dengan orang lain dalam komunikasi yang hidup; dia membahasdokumen Abu Dhabi dalam konteks pendidikan. Ahmad Subakhan pernah meneliti dokumen Abu Dhabi dengan judul penelitian "Semangat Moderasi dalam Watsiiqoh Al-Ikhwah Al-Insaniyah Min Ajli As-Salaam Al'Alamy Wa Al-'Aisy Al- Mustarok", ${ }^{3}$ dari penelitian tersebut dia menemukan bahwa ada semangat moderasi dalam dokumen Abu Dhabi yaitu agar setiap pemeluk agama sadar tentang tujuan diciptakannya, kembali kepada ajaran otentik agama yang menganjurkan perdamaian dan tidak melahirkan paham ekstrimis dan radikalis, moderat merupakan indikator pemahaman agama yang paripurna, dan keyakinan agama merupakan hal berkaitan dengan kerelaan; akan tetapi, pembahasan yang dilakukannya terhadap dokumen Abu Dhabi masih pembahasan umum. Berdasarkan penelitian-penelitian terdahulu tersebut, kebaharuan yang ditawarkan oleh penelitian ini adalah penelitian ini hendak meneliti dokumen Abu Dhabi secara spesifik dengan mengambil fokus pada artikel 23-24 dan juga penelitian ini menggunakan gagasan Theology of Mar-gin dari Raymundus Sudhiarsa dan dokumen Fratelli Tutti untuk mengembangkan gagasan tentang dialog antaragama yang dibahas dalamdokumen Abu Dhabi artikel 23-24 karena ada kesejajaran ide antara dokumen Abu Dhabi artikel 23-24 dengan gagasan Theology of Margin dari Raymundus Sudhiarsa dan dokumen Fratelli Tutti.

Metodologi yang digunakan di dalam penelitian ini adalah metode deduktif dengan pendekatan analogis. Metode deduktif adalah metode yang mendasarkan penalarannya pada perspektif tertentu, sedangkan pendekatan analogis adalah pendekatan yang melihat adanya kesejajaran gagasan antara

1 Siti Marfuatun, "Pandangan Paus Fransiskus Tentang Perdamaian Dunia Dalam Dokumen Konferensi Global Di Abu Dhabi" (UIN Raden Fatah Palembang, 2021).

2 Konstantinus Frederikus Jawa, "Pendidikan Demokrasi, Persaudaraan, Dan Persatuan Indonesia Dalam Terang Dokumen Persaudaraan Manusia," Jurnal Melintas 35, no. 3 (2019).

3 Achmad Subkhan, "Semangat Moderasi Dalam 'Watsiiqoh Al-Ikhwah Al-Insaniyah Min Ajli As-Salaam Al-'Alamy Wa Al-'Aisy Al-Mustarok,'” Jurnal EduTRAINED 3, no. 2 (2019). 
perspektif tertentu dengan perspektif lain. Objek yang diteliti di dalam penelitian ini adalah umat Katolik Indonesia dalam konteks dialog dengan agama-agama yang ada di Indonesia. Tujuan dari penelitian ini adalah untuk menyadarkan umat Katolik Indonesia akan posisi pentingnya di dalam dia- log dengan agama-agama lain dan bagaimana dialog dengan agama-agama lain ini dikerjakan oleh mereka.

\section{Literature Review}

Latar belakang munculnya Dokumen Abu Dhabi adalah buah dari kunjungan Paus Fransiskus ke Uni Emirat Arab (UEA). Kunjungan bersejarah tersebut telah menancapkan tonggak sejarah di dalam dialog antaragama. Dalam kunjungan tersebut, Paus Fransiskus berjumpa dengan Imam Besar AlAzhar di Abu Dhabi pada tanggal 4 Febuari 2019. Dari perjumpaan antarkeduanya, lahirlah Document on Human Fraternity for World Peace and Living Together. Dokumen tersebut telah ditandatangani oleh kedua pemimpin agama tersebut dan menjadi peta jalan yang akan mengarahkan semua orang untuk mengusahakan perdamaian dan keharmonisan di dalam tata hidup bersama di atara umat beragama.

Isi Dokumen Abu Dhabi Artikel 23 adalah sebagai berikut: “Tujuan pertama dan terpenting dari agama adalah percaya kepada Allah, menghormati-Nya dan mengundang semua laki-laki dan perempuan untuk percaya bahwa alam semesta ini bergantung pada Allah yang mengaturnya. Dia adalah Pencipta yang telah membentuk kita dengan kebijaksanaan ilahiNya dan telah memberi kita karunia kehidupan untuk dilindungi. Ini adalah hadiah dan tidak seorang pun berhak untuk mengambil, mengancam, atau memanipulasinya semaunya. Memang, setiap orang harus menjaga karunia kehidupan ini dari awalnya hingga akhirnya yang alami. Karena itu kami mengutuk semua praktik yang mengancam kehidupan seperti genosida, aksi terorisme, pemindahan yang dipaksa, perdangan manusia, aborsi, dan euthanasia. Kami juga mengutuk kebijakan yang mempromosikan praktikpraktik itu." ${ }^{4}$

Sementara itu, isi dari Dokumen Abu Dhabi Artikel 24 adalah sebagai berikut: "Selain itu, kami dengan tegas menyatakan bahwa agama tidak boleh menghasut orang kepada perang, sikap kebencian, permusuhan, dan ekstrimisme, juga tidak boleh menghasut kepada kekerasan atau pertumpahan darah. Kenyataan tragis ini terjadi karena orang menyimpang dari ajaran agama. Itulah hasil dari manipulasi politis terhadap agama-agama dan dari interpretasi yang dibuat oleh kelompok-kelompok religius yang, dalam perjalanan sejarah, telah mengambil manfaat dari dampak kuat sentimen

4 Paus Fransiskus and Ahmad Al-Tayyeb, Dokumen Abu Dhabi: Dokumen Tentang Persaudaraan Manusia Untuk Perdamaian Dunia Dan Hidup Bersama (Jakarta: Obor, 2019). 
agama pada hati orang dengan tujuan untuk membuat mereka bertindak dengan cara yang tidak ada hubungannya dengan kebenaran agama. Ini dilakukan untuk mencapai tujuan-tujuan yang bersifat politis, ekonomis, duniawi, dan picik. Karena itu kami menyerukan kepada semua pihak agar berhenti menggunakan agama untuk menghasut kepada kebencian, kekerasan, ekstrimisme dan fanatisme buta, dan menahan diri dari menggunakan nama Allah untuk membenarkan tindakan pembunuhan, pengasingan, terorisme, dan penindasan. Kami meminta ini karena kami bersama-sama percaya kepada Allah yang tidak menciptakan manusia untuk dibunuh atau saling bertarung, atau disiksa atau dihina dalam situasi hidup mereka. Allah Yang Mahakuasa tidak perlu dibela oleh siapa pun dan tidak ingin nama-Nya digunakan untuk meneror orang." ${ }^{5}$

Ada beberapa poin penting yang ditekankan di dalam dokumen Abu Dhabi artikel 23-24. Beberapa poin penting tersebut adalah sebagai berikut:

1. Tujuan Agama

2. Nilai Luhur Kehidupan

3. Perdamaian

4. Interpretasi Ajaran yang Benar

5. Semua Manusia Bersaudara.

Poin-poin yang ditekankan di dalam dokumen Abu Dhabi artikel 23-24 ini kemudian menjadi poin-poin pokok di dalam pembahasan dari penelitian ini.

\section{Pembahasan}

\subsection{Tujuan Agama}

Dalam dokumen Abu Dhabi artikel 23 dikatakan bahwa "tujuan pertama dan terpenting dari agama adalah percaya kepada Allah, menghormati-Nya dan mengundang semua laki-laki dan perempuan untuk percaya bahwa alam semesta ini bergantung pada Allah yang mengaturnya." ${ }^{6}$ Dengan demikian, menurut dokumen Abu Dhabi artikel 23, agama adalah lembaga yang seharusnya mengajarkan kepada umatnya tentang percaya kepada Allah, percaya bahwa alam semesta bergantung pada Allah yang mengaturnya, serta untuk menghormati-Nya. ${ }^{7}$ Walaupun agama-agama itu berbeda-beda, namun tujuan agama-agama itu adalah satu, yaitu mengajak umatnya untuk menyadari kehadiran Yang Ilahi. Yang Ilani inilah yang menciptakan segala sesuatu. Semua agama pasti mengajarkan keyakinan tersebut dalam ajarannya. Sebagai rasa syukur dari manusia atas segala karya penciptaan dan kebaikanNya, maka manusia berusaha untuk menghormati-Nya. Keberagaman agama

5 Ibid.

6 Ibid.

7 Bdk. Ibid. 
akhirnya disatukan oleh satu tujuan yang sama, yakni percaya kepada Yang Ilahi dan berusaha untuk menghormati-Nya. Penghormatan kepada Yang Ilahi juga harus berdampak pada penghormatan terhadap sesama dan kehidupan mereka. Dalam dialog antaragama, tujuan ini harus mendapat tempat terdepan daripada ritus-ritus atau doktrin-doktrin yang terdapat di dalam masingmasing agama.

Seiring berjalannya waktu, urbanisasi dan migrasi terjadi secara bertahap mengubah wajah masyarakat Indonesia. ${ }^{8}$ Kota-kota atau tempat-tempat yang ramai tidak lagi menjadi kota-kota atau tempat-tempat ramai yang monokultur, melainkan multikultur. Banyak orang berpindah ke tempat yang ramai dan maju karena dilandasi oleh motif ekonomi dan fasilitas-fasilitas yang sudah maju. Secara langsung, kehadiran kaum urban atau migran membawa dampak pada kota atau tempat tujuan urbanisasi atau migrasi. Di situ akan terjadi perjumpaan berbagai agama dan kepercayaan. Misalnya Pulau Bali, dulu Pulau Bali terkenal sebagai tempat bagi pemeluk agamaHindu. Akan tetapi, sekarang Pulau Bali tidak hanya dihuni oleh pemeluk agama Hindu, tetapi juga pemeluk agama dan kepercayaan lain.

Negara Indonesia menjamin hak-hak setiap warga negaranya. Jaminan itu telah tertuang di dalam Undang-undang Dasar Republik Indonesia (UUD RI). Dalam kasus agama, negara tidak mendukung agama tertentu. ${ }^{9}$ Tugas berat bagi negara adalah menjaga toleransi dan keharmonisan di dalam masyarakat yang berbeda-beda kultur dan agamanya. Akan tetapi, untunglah Indonesia memiliki Pancasila sebagai pandagan hidup dan ideologi untuk hidup bersama. Pada sila pertama tidak pernah ditekankan untuk beragama menurut aturan agama yang dominan, melainkan beragama kepada Tuhan Yang Maha Esa. Dengan demikian, semua rakyat Indonesia itu beribadahkepada Allah yang satu, yaitu Allah yang telah menciptakan langit dan bumi beserta kehidupan di dalamnya. Hal ini merupakan hal yang sangat sesuai dengan tujuan dari agama yang disuarakan oleh Dokumen Abu Dhabi artikel 23.

Umat Katolik merupakan minoritas di Indonesia, kecuali di beberapa daerah yang secara geografis merupakan pinggiran negara seperti di Pulau Flores, Timor, Sulawesi Utara, dan Sumatera Utara, serta Kalimantan Barat. ${ }^{10}$ Di tempat di mana umat Katolik menjadi minoritas, kecenderungannya mereka akan mengalami diskriminasi dan ancaman dari agama lain. Dalam situasi inilah mereka ditantang untuk keluar untuk menjalin relasi dengan agamaagama lain. Akan tetapi, di tempat di mana umat Katolik menjadi mayoritas, kecenderungannya mereka akan mengalami kebebasan beragama

8 Raymundus Sudhiarsa, "Theology of Margin: Christian Experience in a Multicultural Context," Studia Philosophica et Theologica 4, no. 2 (2004): 126.

9 Ibid., 128.

10 Ibid., 129. 
dan perdamaian karena tidak ada agama mayoritas lain yang mengancam dan mendiskriminasi. Dalam situasi seperti ini, umat Katolik diajak untuk mengayomi agama-agama minoritas sebagai pengamalan ajaran kasih Yesus Kristus.

Masyarakat Indonesia dipersatukan oleh semacam ingatan kolektif, seperti wawasan nusantara, bhinneka tunggal ika dan pancasila. Ingatan kolektif tersebut menjadi aspek-aspek yang melandasi agama-agama dan kepercayaankepercayaan di Indonesia untuk menjalin persaudaraan dan sekaligus menjadi motivasi untuk mengejar satu tujuan yang sama, yaitu percaya dan menghormati Tuhan. Umat Katolik telah berpartisipasi dalam memori kolektif ini, yaitu sejak peristiwa sejarah dan kesepakatan negara, pada era berdirinya Republik. ${ }^{11}$ Label sebagai pendatang memang dapat menciutkan kehendak baik umat Katolik dalam berpartisipasi untuk negara. Akan tetapi, umat Katolik harus ingat bahwa mereka masih memiliki misi yang harus dijalankandi tanah Indonesia. Misi tersebut bersumber dari misteri peristiwa inkarnasi,di mana Yesus Kristus yang adalah Allah menjadi manusia dan hadir di tengah-tengah kehidupan manusia untuk berdialog dengan persoalan- persoalan manusia. Misi umat Katolik untuk hadir di tengah-tengah masyarakat Indonesia dan berdialog dengan situasi multidimensi Indonesia merupakan bagian dari proyek Tuhan untuk dunia tersebut (Missio Dei).

Umat Katolik dikatakan sebagai 'pendatang', 'tamu', 'orang luar' atau apapun istilahnya, hanya punya satu pilihan, yaitu terus menerus mengedepankan dialog dengan agama-agama dan kepercayaan-kepercayaan lain. Seharusnya umat Katolik memandang agama-agama dan kepercayaan lain itu sebagai tetangga yang harus diajak bekerjasama, bukan malah didiamkan begitu saja. Setiap orang memandang orang lain sebagai tetangga sejatinya harus berjalan seiring menuju masa depan yang sama. ${ }^{12}$ Mereka bersama-sama bekerjasama untuk saling bahu-membahu mengusahakan cinta damai, kebaikan, kesetiaan, dan nilai-nilai keutamaan lainnya. Perbedaan umat Katolik dengan agama-agama dan kepercayaan-kepercayaan lain bukanlah sesuatu yang membatasi, melainkan sesuatu yang menyatukan mereka dalam masyarakat majemuk dan multikultural. Mereka harus memupuk atau mengembangkan semangat saling ketergantungan dan kerjasama, yang berakar pada pengalaman Tuhan yang berhubungan dengan dunia dan kesetiaan kepada entitas yang lebih besar di luar kelompok atau komunitas seseorang. ${ }^{13}$ Dari dialog dan kerjasama antara umat Katolik denganagamaagama dan kepercayaan-kepercayaan lain diharapkan muncul kesadarankesadaran baru di dalam tata hidup bersama sebagai tetangga, seperti toleransi, penghormatan kepada hak-hak minoritas, dan penghargaan terhadap keanekaragaman.

11 Ibid., 133.

12 Ibid.

13 Ibid., 133-134. 
Sekali lagi perlu untuk ditegaskan bahwa umat Katolik Indonesia merupakan bagian integral dari masyarakat Indonesia. Umat Katolik telah berpartisipasi dalam pembangunan bangsa dan juga memiliki kesamaan visi dengan warga negara lainnya, yaitu mengejar kebaikan bersama. ${ }^{14}$ Misi Gereja Katolik itu tidak terlepas dari misi Tuhan (Missio Dei) karena Gereja Katolik sejatinya menghadirkan diri sebagai hamba Tuhan. Partisipasi dalam misi ini pada dasarnya berarti bahwa ini bukanlah misi dari dalam Gereja Katolik itu sendiri, tetapi misi Tuhan. ${ }^{15}$ Pemahaman ini juga berarti bahwa semua kelompok, baik yang dominan maupun yang minoritas harus dianggap sebagai partisipan dalam kehidupan publik untuk mengejar kebaikan bersama, yaitu keselamatan semua orang. ${ }^{16}$ Dengan demikian, bersama dengan semua kelompok yang ada, Gereja Katolik bersama-sama bergerak melampaui perbedaan etnis dan agama yang membatasi menuju semangat gotong royong untuk mengusahakan tercapainya Proyek Ilahi, yaitu hadirnya Kerajaan Allah di dunia.

Hakekat Gereja (ekklesia) adalah pelaksana dari misi Allah, maka Gereja sebagai organisasi dan organisme bertanggungjawab penuh pada pelaksanaan tugas yang diberikan oleh Allah. ${ }^{17}$ Sebagai bagian dari Proyek Ilahi (Missio Dei), tanggung jawab Gereja adalah untuk kemanusiaan secara keseluruhan, orangorang di dunia ini (tetangga kita), terlepas dari afiliasi primordial mereka. ${ }^{18}$ Tanggungjawab terhadap sesama ini mendapatkan porsi yang tidak kalah penting di dalam dialong antaragama. Tanggungjawab ini muncul karena manusia menyadari bahwa mereka sama-sama merupakan makhluk yang diciptakan oleh Tuhan menurut gambar dan rupa-Nya, maka mereka perlu saling peduli terutama kepada sesama yang lemah dan tidak berdaya. Sebagai umat Allah, Gereja itu tidak lain daripada komunitas beriman yang mengalami sukacita keselamatan karena perjumpaan dengan Yesus Kristus. ${ }^{19}$ Karena itu, tanggungjawab Gereja terhadap sesama ini bertujuan untuk mewujudkan tugas perutusan Yesus Kristus di dunia.

Umat Katolik adalah 'pendatang' di dunia, sama seperti Yesus Kristus adalah 'pendatang' di dunia. Karena dianggap sebagai 'pendatang', makaumat Katolik tidak punya pilihan lain kecuali menjelma di tengah-tengah'pribumi' (penduduk setempat). ${ }^{20}$ Dalam menghadirkan diri di tengah-tengah

14 Ibid., 134.

15 Ibid.

16 Ibid.

17 Fransiskus Irwan Widjaja, Daniel Ginting, and Sabar Manahan Hutagalung, “Teologi Misi Sebagai Teologi Amanat Agung," Thronos: Jurnal Teologi Kristen 1, no. 1 (2019): 24.

18 Sudhiarsa, "Theology of Margin: Christian Experience in a Multicultural Context," 134.

19 Raymundus Sudhiarsa, "Murid-Murid Yang Diutus: Sukacita Gereja Indonesia," in Menjadi Gereja Indonesia Yang Gembira Dan Berbelaskasih (Dulu, Kini, Dan Esok), ed. Raymundus Sudhiarsa and Paulinus Yan Olla (Malang: STFT Widya Sasana, 2015), 418-419.

20 Sudhiarsa, "Theology of Margin: Christian Experience in a Multicultural Context," 135. 
'pribumi' tidak akan lengkap kalau tidak menghadirkan diri dalam konteks kultural. Umat Katolik sebagai 'pendatang' seharusnya berusaha untuk masuk ke dalam konteks kultural dari umat agama lain, karena konteks kultural banyak berpengaruh terhadap cara pandang dari umat yang beragama lain tersebut. Apakah umat Katolik sebagai 'pendatang' tidak dapat memberikan sumbangan apa-apa bagi 'penduduk setempat'? Tentu umat Katolik dapat berkonstribusi terhadap 'penduduk setempat' dengan kekayaan iman yang dimilikinya. Umat Katolik dapat memperkaya budaya setempat dengan nilainilai iman Kristiani yang dimilikinya.

\subsection{Nilai Luhur Kehidupan}

Tema mengenai nilai luhur kehidupan merupakan tema yang sangat penting untuk dibahas di dalam dialog antaragama.Menurut dokumen Abu Dhabi artikel 23, kehidupan adalah hadiah dari Tuhan yang tidak seorang pun berhak untuk mengambil, mengancam, ataupun memanipulasinya semaunya. ${ }^{21}$ Kehidupan adalah anugerah terindah dari Tuhan kepada umat Manusia yang harus dilindungi dan dijaga.Semua agama tentu mengajarkan hal yang sama tentang betapa berharganya nilai kehidupan ini. Kehidupan manusia ini berharga tidak hanya sejak dari lahirnya, tetapi seluruh kehidupan manusia itu berharga, bahkan ketika manusia itu tua dan sakit, kehidupannya itu pun berharga. Setiap orang harus menjaga karunia kehidupan ini dari awalnya hingga akhirnya yang alami. ${ }^{22}$ Maka dari itu, semua pemimpin agama, terkhusus Paus Fransiskus sangatmengutuk semua praktik yang mengancam kehidupan seperti genosida, aksi terorisme, pemindahan yang dipaksa, perdagangan manusia, aborsi, dan euthanasia. ${ }^{23}$

Di tengah dunia dewasa ini, berbagai bentuk ketidakadilan terus terjadi, dipicu oleh gagasan antropologis yang dangkal dan oleh model ekonomi yang berbasis keuntungan yang dengan tanpa ragu menghisap, menyingkirkan dan bahkan membunuh umat manusia. ${ }^{24}$ Manusia melihat manusia yang lainnya bukan sebagai sesama manusia, melainkan manusia melihat manusia yang lainnya sebagai alat atau sarana yang mendatangkan keuntungan. Dengan demikian yang terjadi adalah manusia memperdaya manusia yang lainnya untuk mendapatkan keuntungan sebesar-besarnya bagi dirinya. Sementara satu bagian dari umat manusia hidup dalam kemewahan, bagian lain terlihat martabatnya disangkal, direndahkan atau diinjak-injak, serta hak-haknya yang paling dasar dikesampingkan atau dilanggar. ${ }^{25}$ Dalam situasi inilah umat

21 Fransiskus and Al-Tayyeb, Dokumen Abu Dhabi:Dokumen Tentang Persaudaraan Manusia Untuk Perdamaian Dunia Dan Hidup Bersama, artikel 23.

22 Ibid.

23 Ibid.

24 Paus Fransiskus, Fratelli Tutti (Asisi: Tanpa Penerbit, 2020), artikel 22.

25 Ibid. 
Katolik beserta dengan umat dari agama-agama lain seharusnya bersatu padu untuk bersuara menentang ketidakadilan yang terjadi tersebut.

Perjuangan untuk menentang ketidakadilan yang mengancam nilai luhur kehidupan manusia harus dimulai terhadap manusia yang paling lemah. Manusia yang paling lemah itu adalah anak-anak, orang difabel, orang lanjut usia, dan kaum perempuan. Kaum perempuan sering mengalami situasi pengucilan, penganiayaan dan kekerasan, karena mereka seringkali kurang mampu untuk membela hak-hak mereka. ${ }^{26}$ Ketidakmampuan untuk membela hak-hak mereka juga dialami oleh anak-anak, orang difabel, dan orang lansia. Orang difabel dan orang lanjut usia kerapkali mengalami bahwa kehidupan mereka dianggap membebani hidup orang lain, sehingga kerapkali pula diabaikan.

Persoalan mengenai perbudakan juga merupakan persoalan ketidakadilan yang mengancam nilai luhur kehidupan. Saat ini, sebagaimana pula seperti di masa lalu, perbudakan berakar pada pandangan yang memungkinkan manusia diperlakukan sebagai objek. ${ }^{27}$ Entah dengan paksaan, atau tipu muslihat atau dengan tekanan fisik atau psikologis, pribadi manusia yang diciptakan dalam gambaran dan keserupaan dengan Allah dirampas kebebasannya, dijual dan dilecehkan untuk menjadi milik orang lain. ${ }^{28}$ Asisten rumah tangga yang tidak dibayarkan gajinya dan buruh yang memperoleh gaji yang tidak adil adalah bentuk-bentuk dari perbudakan kontemporer yang menghisap seperti hewan lintah.

Perempuan-perempuan pun tidak luput menjadi sasaran perbudakan untuk memuaskan nafsu para lelaki hidung belang. Banyak perempuan akhirnya mengandung anak dari perbudakan nafsu lelaki hidung belang. Penyimpangan yang melampaui segala batas terjadi dengan merendahkan perempuan dan memaksa mereka untuk menggugurkan. ${ }^{29}$ Perbudakan ini harus dilawan dengan sekeras-kerasnya karena perbudakan ini telah melecehkan martabat perempuan dan membunuh kehidupan dalam bentuk pengguguran.

Tindakan membunuh kehidupan juga dapat terjadi dalam bentuk menjual organ tubuh manusia. Pelaku yang melakukan tindakan kekejianseperti itu tidak dapat disebut manusia lagi. Pelaku tersebut telah berlaku seperti binatang karena mereka tidak dapat melihat kodrat kemanusiaan di dalam diri orangorang yang organ-organnya mereka ambil untuk dijual. Perdagangan orang dan bentuk-bentuk perbudakan kontemporer menjadi persoalan mendunia yang perlu ditanggapi secara serius oleh semua umat manusia, karena organisasi-organisasi kriminal memanfaatkan jaringan glo-

26 Ibid., artikel 23.

27 Ibid., artikel 24.

28 Ibid.

29 Ibid. 
bal untuk mencapai tujuan mereka, usaha-usaha untuk menghapuskan fenomen ini membutuhkan pula suatu upaya bersama dan, tentu saja, upaya global dari berbagai sektor dalam masyarakat. ${ }^{30}$

Perang, serangan teroris, dan penganiayaan rasial atau agama juga merupakan tindakan-tindakan yang tidak menghormati kehidupan. Tindakan-tindakan tersebut membuat manusia takut untuk menjalin relasi dengan manusia yang lain. Sebagai akibatnya, situasi yang mengancam tersebut membuahkan ketidakpercayaan dan membuat orang menarik dirike dalam ruang aman dirinya sendiri. ${ }^{31}$ Kendati situasinya begitu mengancam, umat Katolik harus mampu melampaui rasa takut yang ditimbulkan olehsituasi yang mengancam tersebut. Umat Katolik mesti berani berdialog dan mengajak umat dari agama-agama lain untuk melawan situasi-situasi yang mengancam, seperti perang, serangan teroris, dan persekusi atas nama agama atau rasial.

Sekali lagi, manusia menjumpai godaan untuk membangun budaya tembok, membangun benteng-benteng, tembok di hati, benteng di atas tanah, supaya menghindari perjumpaan dengan budaya lain, dengan orang-orang lain. ${ }^{32} \mathrm{Hal}$ ini dapat memperlebar jurang ketidakpedulian dan eksklusivitas. Mereka membangun tembok yang akan menjadi budak di dalam temboktembok yang mereka dirikan. ${ }^{33}$ Mereka menjadi makhluk yang individualistis, di mana mereka hanya memikirkan kehidupannya sendiri. Mereka tidak peduli bahwa di luar sana ada kehidupan-kehidupan yang hendak dimusnahkan oleh mereka yang telah kehilangan kemanusiannya. Mereka dibiarkan tanpa cakrawala pandang, sebab mereka tidak mengalami pertukaran dengan yang lain. ${ }^{34}$ Mereka berubah menjadi makhluk yang fundamentalis dan berpikiran sempit. Umat Katolik seharusnya tidak tergoda untuk ikut membangun tembok, meski harus diakui bahwa mereka sendiri mengalami keterancaman dari pihak yang dominan. Dalam situasi seperti ini, umat Katolik seharusnya membuka lebar-lebar pintu rumahnya dan mengundang saudara-saudara dari agama-agama lain untuk berdialog tentang isu-isu kehidupan yang direndahkan dan dilecehkan martabatnya. Selanjutnya, umat Katolik beserta umat dari agama-agama lain mengambil tindakan konkret untuk menentang ketidakadilan-ketidakadilan yang merendahkan dan melecehkan martabat kehidupan.

\subsection{Perdamaian}

Dokumen Abu Dhabi artikel 24 menegaskan bahwa agama tidak boleh

30 Ibid.

31 Ibid., artikel 26.

32 Ibid., artikel 27.

33 Ibid.

34 Ibid. 
menghasut orang kepada perang, sikap kebencian, permusuhan, dan ekstrimisme, juga tidak boleh menghasut kepada kekerasan atau pertumpahan darah. ${ }^{35}$ Agama bukanlah sesuatu yang otonom, melainkan berada dalam suatu realitas obyektif yang secara signifikan mempengaruhi, baik interpretasi maupun aktualisasi dari agama tersebut. ${ }^{36}$ Saat ini manusia dihadapkan pada realitas yang sulit tentang agama. Mereka berharap bahwa melalui agama yang mereka ikuti dapat membantu mereka untuk dapat berelasi denganTuhan dan sesama. Akan tetapi, realita yang terjadi justru sebaliknya, agama telah digunakan oleh orang-orang yang tidak bertanggungjawab untuk menyebarkan kebencian, permusuhan, tindakan ekstrimisme, dan kekerasan yang mengakibatkan pertumpahan darah. Situasi ini tidak boleh dibiarkan dan umat Katolik perlu mengambil sikap untuk membendung pengaruh orangorang yang tidak bertanggungjawab tersebut di dalam dialog dengan agamaagama dan kepercayaan-kepercayaan lain. Tema tentang perdamaian dapat menjadi tema penting dan mendesak untuk dibahas dalam dialog denganagamaagama dan kepercayaan-kepercayaan lain.Menurut dokumen Abu Dhabi, perdamaian adalah nilai transendental yang menjadi titik tolak untuk beberapa pertemuan yang ditandai dengan suasana persahabatan dan persaudaraan, di mana satu sama lain berbagi sukacita, kesedihan, dan masalah-masalah dunia saat ini. ${ }^{37}$

Abad ke-20 diidentifikasikan sebagai masa paling kejam dalam sejarah manusia, sedangkan pada abad ke-21 tidak ada tanda-tanda berakhirnya kekerasan dan terorisme. ${ }^{38}$ Bahkan sampai sekarang ini, Indonesia masih berada di bawah bayang-bayang terorisme. Kejadian bom bunuh diri yang terjadi di Katedral Makassar pada tanggal 28 Maret 2021 menjadi tanda bahwa terorisme masih tetap eksis untuk menyebarkan ketakutan di antara orangorang yang sedang beribadah, terkhusus umat Katolik. Selain terorisme, Indonesia juga masih berada di bawah bayang-bayang konflik dan kekerasan. Indonesia juga telah mengalami beberapa dekade waktu yang sulit: konflik etnis, bentrokan komunal dan kekerasan massa, dan sebagainya, biasanya diberitakan bernuansa SARA (suku, agama, ras dan divisi sosial) yang menunjukkan ikatan primordial (identitas) dariorang-orang yang 'dipaksa' untuk tinggal di satu 'wilayah' bernama Indonesia. ${ }^{39}$

35 Fransiskus and Al-Tayyeb, Dokumen Abu Dhabi:Dokumen Tentang Persaudaraan Manusia Untuk Perdamaian Dunia Dan Hidup Bersama (Jakarta:Obor, 2019).

36 Agustinus Wisnu Dewantara, "Pancasila Dan Multikulturalisme Indonesia," Studia Philosophica et Theologica 15, no. 2 (2015): 119.

37 Fransiskus and Al-Tayyeb, Dokumen Abu Dhabi:Dokumen Tentang Persaudaraan Manusia Untuk Perdamaian Dunia Dan Hidup Bersama, artikel 2.

38 Sudhiarsa, "Theology of Margin: Christian Experience in a Multicultural Context," 125126.

39 Ibid., 126. 
Konstruksi sosial seharusnya mempromosikan apa yang disebut 'budaya harmoni' dengan nilai-nilai tolerannya terhadap perbedaan. Pengkotakkotakan atas dasar SARA seharusnya didekonstruksi, selanjutnya masyarakat Indonesia berusaha untuk mengkonstruksi ulang masyarakat Indonesia menjadi masyarakat yang bersatu di dalam keanekaragaman sesuai semboyan negara Indonesia, yaitu berbeda-beda tetapi tetap satu juga. Sebenarnya tidak ada untungnya kalau masyarakat Indonesia jatuh pada fanatisme SARA. Hal itu hanya menimbulkan sikap mementingkan kelompok masing-masing saja tanpa mau tahu apa yang dirasakan dan digulati oleh kelompok-kelompok lain. Alhasil, masing-masing kelompok hanya akan membangun tembok- tembok masing-masing, seperti yang dikatakan oleh Paus Fransiskus, untuk menyembunyikan diri mereka di dalam rasa aman.

Umat Katolik seharusnya tidak ikut-ikutan menjadi kelompok yang mencari rasa aman dan membangun tembok setinggi-tingginya untuk melindungi mereka. Dalam situasi yang diliputi konflik dan kekerasan, umat Katolik seharusnya ikut aktif mengusahakan perdamaian melalui jalan dialog dengan semua orang yang berkehendak baik tanpa dibatasi oleh SARA. Setiap kelompok akhir-akhir ini semakin mengelaborasi dan menjalin ikatan yang dalam dengan identitasnya pada garis etnis, agama, ras, dan sebagainya. Akan tetapi, tidaklah demikian dengan umat Katolik, walaupun di dalam umat Katolik sendiri terdiri dari berbagai ras, kedaerahan, suku, maupun etnis, umat Katolik tetap memelihara identitas mereka sebagai murid-murid Yesus Kristus yang mempunyai tugas suci dari Sang Guru untuk menyebarkan kasihdan perdamaian.

Beberapa provinsi mengkonsolidasikan identitas daerah mereka berdasarkan komunitas yang dominan secara meriah - misalnya 'Pura Seribu' di Bali adalah untuk umat Hindu, 'Seribu Masjid' di Lombok adalah untuk Muslim. ${ }^{40}$ Identitas ini menjadi wadah yang memberikan rasa aman bagi anggota-anggota kelompok yang dominan di daerah provinsi tersebut, tetapi tidak memberikan rasa nyaman untuk kelompok-kelompok minoritas di daerah tersebut. Kelompok minoritas di perkotaan mengalami diskriminasi dan sebagian besar menjadi korban gejolak sosial dan bentrokan komunal. ${ }^{41}$ Dengan demikian, kelompok minoritas jauh dari kata harmoni ketika mereka berhadapan dengan kelompok yang dominan. Maka dari itu, kelompok dominan perlu keluar dari diri mereka sendiri dan seharusnya mereka berusaha untuk merangkul kelompok-kelompok minoritas dalam semangat persaudaraan dan perdamaian.

Ketika kelompok dominan tidak mampu mengayomi dan mengakomodasi kebutuhan dari kelompok minoritas, kedua kelompok tersebut akan selalu berada di bawah bayang-bayang prasangka, kebencian, dan bila sudah

40 Ibid., 128.

41 Ibid. 
memuncak semua itu akan meletus menjadi konflik yang tiada berkesudahan. Mempertimbangkan semua kesulitan tersebut, masyarakat multikultural ini ternyata tidak dapat mendorong interaksi yang intensif dan kontak budaya produktif masyarakatnya. ${ }^{42}$ Lebih buruk lagi, Indonesia telah menjadi 'medan kerusuhan' di mana kekerasan demi kekerasan meletus yang menjadikan Indonesia 'tanah tumpah darah' yang sesungguhnya. ${ }^{43}$ Hal ini terjadi karena kelompok-kelompok masih mengarah pada loyalitas primordial. Mereka masih tersandera oleh sentimen ghetto.

\subsection{Interpretasi Ajaran yang Benar}

Menurut dokumen Abu Dhabi, ajaran yang benar adalah ajaran yang mengajarkan bahwa Allah itu menciptakan semua manusia setara dalam hak, kewajiban, dan martabat, serta Allah memanggil mereka untuk hidup sebagai saudara, untuk memenuhi bumi dan untuk menyebarkan nilai-nilai kebaikan, cinta, dan kedamaian. ${ }^{44}$ Sementara itu, interpretasi adalah upaya untuk menerangkan mengenai arti dari sesuatu. Karena itu, doktrin-doktrin dari agama harus diinterpretasikan dalam terang ajaran yang benar tersebut.

Saat ini telah terjadi penyesatan-penyesatan doktrin agama yang dapat mengancam keharmonisan di dalam tata hidup bersama. Doktrin agama telah diselewengkan dari ajaran yang benar. Penyesatan doktrin agama ini nampak dalam ajaran yang menghalalkan untuk membunuh manusia yang berlainan agama atau kepercayaan. Kalau manusia itu percaya kepada Allah dan menghormati-Nya, tentu manusia tidak akan melakukan kekerasan dan membunuh sesamanya, karena tindakan menghancurkan ciptaan sama saja merupakan tindakan yang tidak menghormati penciptanya. Itulah hasil dari manipulasi politis terhadap agama-agama dan dari interpretasi yang dibuat oleh kelompok-kelompok religius yang, dalam perjalanan sejarah, telah mengambil manfaat dari dampak kuat sentimen agama pada hati orang dengan tujuan untuk membuat mereka bertindak dengan cara yang tidak ada hubungannya dengan kebenaran agama. ${ }^{45}$

Dokumen Abu Dhabi artikel 24 menegaskan bahwa semua pihak harus berhenti menggunakan agama untuk menghasut kepada kebencian, kekerasan, ekstrimisme dan fanatisme buta, dan menahan diri dari menggunakan nama Allah untuk membenarkan tindakan pembunuhan, pengasingan, terorisme, dan penindasan. ${ }^{46}$ Semua tindakan yang merusak dan

42 Ibid., $128-129$.

43 Ibid., 129.

44 Fransiskus and Al-Tayyeb, Dokumen Abu Dhabi:Dokumen Tentang Persaudaraan Manusia Untuk Perdamaian Dunia Dan Hidup Bersama, artikel 4.

45 Ibid., artikel 24.

46 Ibid. 
menghancurkan kehidupan manusia tidak pernah dibenarkan oleh agama manapun. Kalau ada ajaran yang mengajarkan untuk membunuh manusia yang berlainan agama atau kepercayaan berarti ada interpretasi yang salah dari sebuah doktrin agama, yang dilakukan oleh orang-orang yang ingin membuat kekacauan. Doktrin agama tidak boleh diinterpretasikan secara sembarangan apalagi doktrin agama digunakan untuk membuat kekacauan dan merusak keharmonisan dalam tata hidup bersama. Doktrin agama harus diinterpretasikan dalam kerangka kasih dan perdamaian; itulah interpretasi ajaran agama yang benar.

Sebuah perziarahan perdamaian antar agama-agama adalah mungkin dan titik tolaknya haruslah dari cara Allah dalam memandang segalanya. ${ }^{47}$ "Allah tidaklah memandang dengan mata, Allah memandang dengan hati- Nya. Dan kasih Allah adalah sama untuk siapapun, apapun agamanya. Bahkan kalau mereka itu ateis, kasih-Nya tetap sama." ${ }^{48}$ Kalau Allah mengasihi siapapun tanpa Dia memandang manusia dari agama mana, maka tidak seorang pun boleh memandang manusia dari agama lain sebagai musuh yang harus dibinasakan. Sebaliknya, seharusnya manusia berusaha untuk menjalin persaudaraan dengan mereka dalam semangat perdamaian. Hal itulah yang semestinya dilakukan di antara manusia-manusia yang berlainan agama. Umat Katolik di sini dapat mengambil posisi sebagai mediator perdamaian dalam dialog dengan agama-agama lain untuk mengusahakan interpretasi ajaran yang benar, yaitu ajaran yang ditafsirkan dalam kerangkan kasih dan perdamaian.

Kesempatan untuk berjumpa dan berdialog dengan agama-agama lain hendaknya diarahkan untuk bertindak bagi kebaikan bersama, seperti pembelaan hak-hak untuk orang-orang yang miskin. Semua ajaran agamapasti mengajarkan untuk berbuat baik bagi sesama. Karena itu, kalau ada agama yang mengajarkan untuk menyakiti sesama, ajaran itu berarti ajaran yang sesat dan sudah seharusnya dilawan. Dalam dialog setiap orang tidak perlu malu dengan latar belakang dari agama atau kepercayaan mana. Demikian pula, mereka tidak perlu malu dan menyembunyikan apa yang mereka yakini dalam agama atau kepercayaan mereka. Hal ini tidak ada kaitannya dengan melonggarkan atau menyembunyikan keyakinan terdalam ketika setiap orang menjumpai sesama yang berpikir berbeda dengan dirinya sendiri, sebab semakin dalam, kuat dan kaya identitas diri mereka, semakin mereka akan sanggup memperkaya sesama dengan sumbangan nyata mereka secara tepat. ${ }^{49}$ "Dalam melakukan dialog dengan agama lain, apapun bentuknya, diperlukan adanya sikap saling terbuka, saling menghormati dan kesediaan untuk mendengarkan yang lain. Sikap-sikap ini diperlukan untuk

47 Fransiskus, Fratelli Tutti, artikel 281.

48 Ibid.

49 Ibid., artikel 282. 
mencari titik temu (kalimatun sawa') antara berbagai agama, karena masingmasing agama mempunyai karakteristik yang unik dan kompleks." ${ }^{\prime 50}$

Umat beriman dari agama dan kepercayaan manapun ditantang untuk kembali kepada sumber-sumber mereka, untuk memusatkan pada apa yang pokok: memuji Allah dan kasih kepada sesama, jangan sampai ajaran-ajaran mereka, diambil dari luar konteks, yang akhirnya mengobarkan bentuk-bentuk penghinaan, kebencian, xenofobia atau penyangkalan akan orang lain. ${ }^{51}$ Setiap penafsiran ajaran agama sudah seharusnya melihat tujuan dari agama. Agama hadir di tengah-tengah manusia mempunyai tujuan untuk membantu manusia agar dapat memuji Allah dan mengasihi sesama. Karena itu, kekerasan tidak mempunyai dasar di dalam ajaran-ajaran agama atau kepercayaan manapun, bahkan di dalam ajaran agama atau kepercayaan yang paling fundamental sekalipun. Sembah bakti yang tulus serta rendah hati kepada Allah berbuah tidak dalam diskriminasi, kebencian dan kekerasan, melainkan dalam penghargaan akan kesucian hidup, penghargaan akan martabat serta kebebasan, komitmen kasih akan kesejahteraan semua. ${ }^{52}$ Maka dari itu, dapat dipahami mengapa Paus Fransiskus sangat menentang tindakan terorisme; mengenai terorisme, beliau mengatakan demikian: "Terorisme dalam segala bentuk serta pewujudannya tersebut harus dikutuk.Keyakinan agama tentang makna sakral akan kehidupan manusia memungkinkan kita untuk mengenali nilai-nilai fundamental kemanusiaan bersama kita, dengan nilainilai tersebut kita dapat dan harus bekerjasama, membangun dan berdialog, memaafkan dan tumbuh; ini akan memungkinkansuara-suara yang berbeda bersatu untuk menciptakan suatu melodi yang agung dan indah, bukan teriakan fanatik kebencian." ${ }^{53}$

Seringkali kekerasan fundamentalis dikobarkan dalam beberapa kelompok, apapun agamanya, oleh para pemimpin agama yang gegabah. ${ }^{54} \mathrm{Para}$ pemimpin agama yang gegabah tersebut adalah pemimpin agama yang hanya mementingkan dirinya sendiri saja. ${ }^{55}$ Sebagai pemuka agama, setiap orang dipanggil untuk sungguh menjadi 'insan dialog', untuk bekerjasama dalam membangun perdamaian tidak sebagai Calo namun sebagai Mediator yang sesungguhnya. ${ }^{56}$ Calo itu bertindak sebagai perantara, tetapi dengantujuan untuk mencari keuntungan bagi dirinya sendiri. Sementara itu, Me- diator itu bertindak sebagai perantara tetapi tidak mencari keuntungan bagi

50 M.Zainuddin, "Pluralisme Dan Dialog Antarumat Beragama," Studia Philosophica et Theologica 5, no. 1 (2005): 44.

51 Fransiskus, Fratelli Tutti, artikel 282.

52 Ibid., artikel 283.

53 Ibid.

54 Ibid., artikel 284.

55 Ibid.

56 Ibid. 
dirinya sendiri, namun ia lebih menyediakan dirinya secara tulus dan total untuk mengusahakan perdamaian di antara umat yang berlainan agama atau kepercayaannya. Paus Fransiskus menegaskan bahwa setiap orang dipanggil untuk menjadi perajin perdamaian, dengan menyatukan bukan memecahbelah, dengan menghapus kebencian dan tidak malahan berpegang padanya, dengan membuka jalan dialog bukan dengan mendirikan tembok-tembok baru. ${ }^{57}$

\subsection{Semua Manusia Bersaudara}

Dokumen Abu Dhabi artikel 24 menegaskan bahwa Allah tidak menciptakan manusia untuk dibunuh atau saling bertarung, atau disiksa atau dihina dalam situasi hidup mereka. ${ }^{58}$ Allah justru memanggil semua umat manusia hidup di dalam persaudaraan. ${ }^{59}$ Persaudaraan insani yang merangkul semua manusia, menyatukan mereka dan menjadikan mereka setara ${ }^{60}$ Gagasan dasar ini mesti ditangkap dengan sebaik-baiknya oleh umat Katolik sebagai tugas sucinya di dalam dialog dengan agama-agama dan kepercayaan-kepercayaan lain. Umat Katolik diajak untuk mengasihi sesama yang lain seperti mereka mengasihi diri mereka sendiri. Kalau dengan diri mereka sendiri saja, umat Katolik berusaha untuk merawat dan menjaganya dengan sebaik-baiknya. Demikian pula, mereka harus lakukan kepada sesama yang lain, yaitu menjaga dan merawat mereka tanpa pandang bulu.

Persahabatan sosial dan persaudaraan universal mengundang pada pengakuan akan keberhargaan setiap pribadi manusia, selalu dan di mana saja. ${ }^{61}$ Kehidupan manusia merupakan sesuatu yang luhur dan tidak boleh dibinasakan atau dimusnahkan. Hal ini merupakan prinsip dasar kehidupan sosial yang cenderung diabaikan dalam berbagai cara oleh mereka yang merasa bahwa hal itu tidak sesuai dengan cara pandang mereka atau membantutujuantujuan mereka. ${ }^{62}$ Pengabaian manusia terhadap pengakuan akan nilai luhur umat manusia telah membuat manusia jatuh ke dalam jurang krisis kemanusiaan. Intinya, tindakan-tindakan 'melawan kodrat' ini - manusia diciptakan dalam keadaan 'amat baik adanya' dan menurut 'gambar dan rupa Allah' (bdk Kej 1:26-31) - adalah kejahatan melawan kemanusiaan. ${ }^{63}$ Manusia kemudian menjadi kehilangan rasa kemanusiaannya kepada

57 Ibid.

58 Fransiskus and Al-Tayyeb, Dokumen Abu Dhabi:Dokumen Tentang Persaudaraan Manusia Untuk Perdamaian Dunia Dan Hidup Bersama (Jakarta:Obor, 2019).

59 Bdk. Ibid., artikel 4.

60 Ibid., artikel 9.

61 Fransiskus, Fratelli Tutti, artikel 106.

62 Ibid.

63 Raymundus Sudhiarsa, "Spiritualitas Interkultural: Berselancar Dalam Era Dialog Antarperadaban," Studia Philosophica et Theologica 9, no. 2 (2009): 169. 
sesamanya. Pada akhirnya, manusia yang kehilangan kemanusiaannya akan memulai babak yang sangat brutal di dalam sejarah umat manusia dengan melakukan pembunuhan massal yang sangat mengerikan. Di dalamnya, aktoraktor pembunuh massal tidak merasa bersalah sama sekali dan itu merupakan tragedi kemanusiaan yang sangat menyeramkan.

Di dalam dialog persaudaraan dengan agama-agama lain tidak hanya mengedepankan nilai kemanusiaan saja, tetapi juga nilai-nilai moral yanglain. Bukanlah sesuatu yang keliru kalau menyebutkan bahwa mencari serta mengupayakan kebaikan sesama dan seluruh umat manusia juga berarti membantu individu-inidividu dan masyarakat menjadi dewasa dalam nilainilai moral yang memajukan perkembangan manusia yang utuh. ${ }^{64}$ Dengan kata lain, nilai-nilai atau sistem nilai yang menggerakkan hidup setiap masyarakat manusia menyebabkan setiap masyarakat atau kelompok budaya memiliki karakternya yang khas. ${ }^{65}$ Setiap masyarakat perlu memastikan bahwanila-nilai moral diteruskan; tanpa itu, hal-hal yang diwariskan adalah egoisme,kekerasan, korupsi dalam berbagai bentuknya, ketidakpedulian dan, akhirnya, suatu kehidupan akan tertutup pada hal-hal yang transendens serta berurat berakar pada kepentingan-kepentingan individual. ${ }^{66}$

Dialog persaudaraan perlu juga menggandeng pranata-pranata lain di dalam kerjasama mengakarkan nilai-nilai moral yang mendukung semangat persaudaraan di hati dan budi manusia sejak usia dini. Pranata-pranata itu adalah keluarga dan sekolah. Keluarga adalah tempat pertama di mana nilainilai kasih dan persaudaraan, kebersamaan dan berbagi, kepedulian dan perhatian akan sesama dihidupi dan diteruskan. ${ }^{67}$ Keluarga adalah juga lingkungan istimewa bagi penerusan iman, diawali dengan tanda-tanda devosi sederhana yang diajarkan oleh ibu kepada anak-anaknya. ${ }^{68}$ Para guru, yang memiliki tugas yang menantang dalam mendidik anak-anak dan orang muda di sekolah dan tempat-tempat lain, hendaknya menyadari bahwa tanggungjawab mereka mencakup pula aspek moral, spiritual dan sosial dalam kehidupan. ${ }^{69}$

Menjalin persaudaraan tidak akan lengkap tanpa aksi solidaritas. Solidaritas menemukan pewujudan konkret dalam pelayanan, yang dapat mengambil berbagai bentuk upaya kepedulian kepada sesama dan pelayanan yang luhur berarti peduli pada yang rentan, anggota keluarga, masyarakat

64 Fransiskus, Fratelli Tutti, artikel 112.

65 Raymundus Sudhiarsa, “Kebahagiaan Dalam Diskursus Lintas Budaya Dan Pesannya Untuk Tugas Pewartaan Gereja," in Di Mana Letak Kebahagiaan?; Penderitaan, Harta, Dan Paradoksnya (Tinjauan Filsafat-Teologis), ed. Edison R.L. Tinambunan and Kristoforus Bala (Malang: STFT Widya Sasana, 2014), 352.

66 Fransiskus, Fratelli Tutti, artikel 113.

67 Ibid., artikel 114.

68 Ibid.

69 Ibid. 
dan orang-orang yang paling rapuh. ${ }^{70}$ Dengan memberikan pelayanan tersebut, para individu belajar untuk mengesampingkan keinginan dan kehendaknya sendiri, hasratnya mengejar kekuasaan, dan berhadapan dengan tatapan konkret mereka yang paling rentan. ${ }^{71}$ Saat ini banyak orang bisa berbicara dengan sangat indah tentang persaudaraan. Akan tetapi, banyak juga kata indah tentang persaudaraan itu tidak diwujudkan dalam aksi solidaritas. Hal ini merupakan sebuah keprihatinan bersama yang harus diperbaiki demi terwujudnya persaudaraan yang tulus dan total di antara umat manusia.

\section{Temuan}

Penelitian ini menemukan bahwa ada lima tema yang dapat digumuli oleh umat Katolik di dalam dialog dengan agama-agama dan kepercayaankepercayaan lain. Tema pertama adalah tentang tujuan dari agama. Tujuan agama adalah membantu manusia untuk percaya kepada Tuhan dan menghormati-Nya. ${ }^{72}$ Tema kedua adalah tentang nilai luhur kehidupan. Perjuangan untuk membela nilai luhur kehidupan harus dimulai pada manusia yang paling rapuh dan rentan, yaitu janin, anak-anak, orang difabel, orang lanjut usia, dan kaum perempuan. ${ }^{73}$ Tema ketiga adalah tentang perdamaian. Perdamaian tidak akan pernah terjadi jika masing-masing manusia mendirikan tembok-tembok yang membatasi dan memisahkan di antara mereka. ${ }^{74}$ Tema keempat adalah tentang interpretasi ajaran yang benar. Ajaran yang benar adalah ajaran yang mengajarkan bahwa Allah itu menciptakan semua manusia setara dalam hak, kewajiban, dan martabat, serta Allah memanggil mereka untuk hidup sebagai saudara, untuk memenuhi bumi dan untuk menyebarkan nilai-nilai kebaikan, cinta, dan kedamaian. ${ }^{75}$ Tema kelima adalah tentang persaudaraan. Persaudaraan harus di- wujudnyatakan di dalam solidaritas dan solidaritas menemukan bentuknya yang konkret di dalam pelayanan yang luhur kepada orang-orang yang rentandan rapuh. ${ }^{76}$

70 Ibid., artikel 115.

71 Ibid., artikel 114.

72 Lihat juga Ridwan Lubis, Agama Dan Perdamaian: Landasan, Tujuan, Dan Realitas Kehidupan, ed. Andi Tarigan (Jakarta: Gramedia Pustaka Utama, 2017).

73 Bdk. Fransiskus, Fratelli Tutti, artikel 23.

74 Lihat juga Sakaria Anwar, "Membangun Kembali Perdamaian/ : Rekonsiliasi Konflik Komunal Berbasis Trust," KRITIS:Jurnal Ilmu Sosial dan Ilmu Politik Universitas Hasanuddin 1, no. 1 (2015).

75 Bdk. Yakobus Banusu dan Antonius Denny Firmanto, "Kebahagiaan dalam Ruang Keseharian Manusia," Forum Filsafat dan Teologi 49, no. 2 (2020).

76 Lihat juga Fransiskus Sulaiman Otor, "Membangun Kembali Dialog Keagamaan: Telaah Deskriptif-Singkat Atas Ensiklik Fratelli Tutti Menurut Paus Fransiskus," Jurnal Dekonstruksi 3, no. 1 (2021). 


\section{Kesimpulan}

Dari pembahasan di atas ada tiga kesimpulan yang dapat ditarik sebagai benang merah. Pertama, dokumen Abu Dhabi artikel 23-24 mengatakan bahwa dialog antaragama harus dapat membantu umat manusia untuk dapat memahami tujuan dari agama, yaitu percaya kepada Tuhan dan menghormatiNya, demikian dalam percaya kepada Tuhan itu manusia diajak untuk menjaga dan melindungi kehidupan yang merupakan karunia Tuhan.Kedua, menurut dokumen Abu Dhabi artikel 24, dialog antaragama merupakan sesuatu yang penting dan mendesak untuk dilakukan karena saat ini agama telah digunakan oleh oknum-oknum tertentu untuk menghasut orang kepada perang, sikap kebencian, permusuhan, dan ekstrimisme, juga agama telahdigunakan untuk menghasut orang kepada kekerasan atau pertumpahan darah. Ketiga, dialog antaragama dapat dilakukan apabila masing-masing manusia tidak lagi membangun tembok-tembok, melainkan berani keluar untuk menjadi mediator perdamaian dan persaudaraan dengan dilandasi semangat solidaritas dalam pelayanan kepada keluhuran kehidupan manusia yang dimulai pada manusia yang paling rapuh dan rentan. Di sinilah umat Katolik harus menyadari dan memahami perannya di dalam dialog antaragama sebagai tugas suci yang mereka terima dari Sang Guru, yaitu Yesus Kristus, ditengah-tengah dunia.

\section{Kepustakaan}

Anwar, Sakaria. "Membangun Kembali Perdamaian: Rekonsiliasi Konflik Komunal Berbasis Trust." KRITIS: Jurnal Ilmu Sosial dan Ilmu Politik Universitas Hasanuddin 1, no. 1 (2015).

Dewantara, Agustinus Wisnu. "Pancasila Dan Multikulturalisme Indonesia." Studia Philosophica et Theologica 15, no. 2 (2015).

Fransiskus, Paus. Fratelli Tutti. Asisi: Tanpa Penerbit, 2020.

Fransiskus, Paus, and Ahmad Al-Tayyeb. Dokumen Abu Dhabi: Dokumen Tentang Persaudaraan Manusia Untuk Perdamaian Dunia Dan Hidup Bersama. Jakarta: Obor, 2019.

Konstantinus Frederikus Jawa. "Pendidikan Demokrasi, Persaudaraan, Dan Persatuan Indonesia Dalam Terang Dokumen Persaudaraan Manusia." Jurnal Melintas 35, no. 3 (2019).

Lubis, Ridwan. Agama Dan Perdamaian: Landasan, Tujuan, Dan Realitas Kehidupan. Edited by Andi Tarigan. Jakarta: Gramedia Pustaka Utama, 2017.

Marfuatun, Siti. "Pandangan Paus Fransiskus Tentang Perdamaian Dunia Dalam Dokumen Konferensi Global Di Abu Dhabi." UIN Raden Fatah Palembang, 2021.

Otor, Fransiskus Sulaiman. “Membangun Kembali Dialog Keagamaan: Telaah 
Deskriptif-Singkat Atas Ensiklik Fratelli Tutti Menurut Paus Fransiskus." Jurnal Dekonstruksi 3, no. 1 (2021).

Subkhan, Achmad. "Semangat Moderasi Dalam 'Watsiiqoh Al-Ikhwah AlInsaniyah Min Ajli As-Salaam Al-'Alamy Wa Al-'Aisy Al-Mustarok.'” Jurnal EduTRAINED 3, no. 2 (2019).

Sudhiarsa, Raymundus. "Kebahagiaan Dalam Diskursus Lintas Budaya Dan Pesannya Untuk Tugas Pewartaan Gereja." In Di Mana Letak Kebahagia-an?; Penderitaan, Harta, Dan Paradoksnya (Tinjauan Filsafat-Teologis), ed-ited by Edison R.L. Tinambunan and Kristoforus Bala. Malang: STFT Widya Sasana, 2014.

"Murid-Murid Yang Diutus: Sukacita Gereja Indonesia." In Menjadi Gereja Indonesia Yang Gembira Dan Berbelaskasih (Dulu, Kini, Dan Esok), edited by Raymundus Sudhiarsa and Paulinus Yan Olla. Malang: STFT Widya Sasana, 2015.

- "Spiritualitas Interkultural: Berselancar Dalam Era Dialog Antarperadaban." Studia Philosophica et Theologica 9, no. 2 (2009).

. "Theology of Margin: Christian Experience in a Multicultural Context." Studia Philosophica et Theologica 4, no. 2 (2004).

Widjaja, Fransiskus Irwan, Daniel Ginting, and Sabar Manahan Hutagalung. "Teologi Misi Sebagai Teologi Amanat Agung." Thronos: Jurnal Teologi Kristen 1, no. 1 (2019).

Yakobus Banusu dan Antonius Denny Firmanto, "Kebahagiaan dalam Ruang Keseharian Manusia," Forum Filsafat dan Teologi 49, no. 2 (2020).

Zainuddin, M. "Pluralisme Dan Dialog Antarumat Beragama." Studia Philosophica et Theologica 5, no. 1 (2005). 
